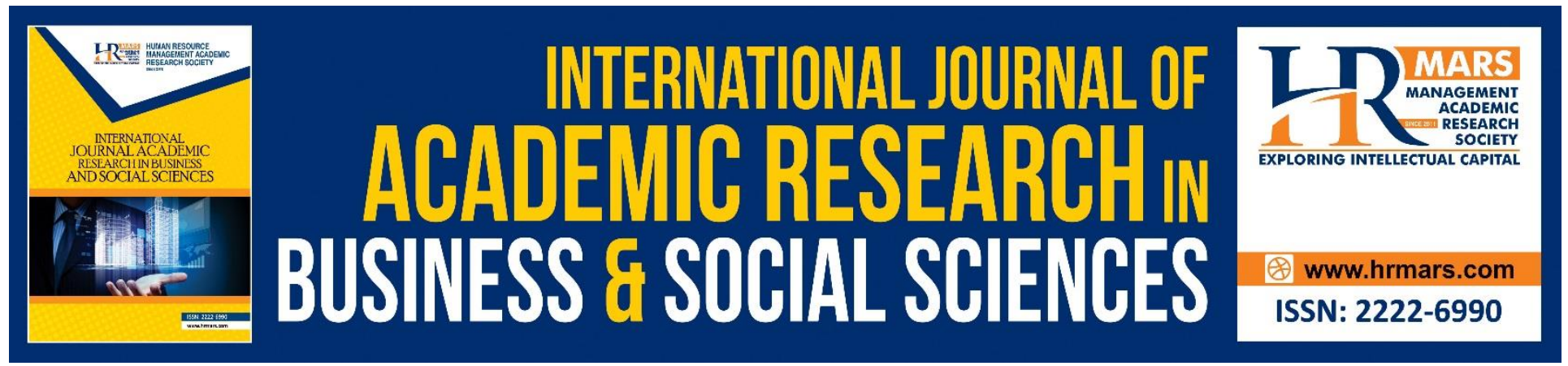

\title{
Assessing The Relationship between Sponsor Image Formation towards Building Positive Sponsor's Image
}

Wan Soraya Wan Abdul Ghani, Nurakmal Ramli, Muhammad Wafaruddin Saipul Bakhry, Nur Farhana Mohd Sah, Tengku Elena Tengku Mahamad

To Link this Article: http://dx.doi.org/10.6007/IJARBSS/v9-i6/5976 DOI: 10.6007/IJARBSS/v9-i6/5976

Received: 16 April 2019, Revised: 24 May 2019, Accepted: 06 June 2019

Published Online: 26 June 2019

In-Text Citation: (Ghani, Ramli, Bakhry, Sah, \& Mahamad, 2019)

To Cite this Article: Ghani, W. S. W. A., Ramli, N., Bakhry, M. W. S., Sah, N. F. M., \& Mahamad, T. E. T. (2019). Assessing The Relationship between Sponsor Image Formation towards Building Positive Sponsor's Image. International Journal of Academic Research in Business and Social Sciences, 9(6), 613-623.

Copyright: (C) 2019 The Author(s)

Published by Human Resource Management Academic Research Society (www.hrmars.com)

This article is published under the Creative Commons Attribution (CC BY 4.0) license. Anyone may reproduce, distribute, translate and create derivative works of this article (for both commercial and non-commercial purposes), subject to full attribution to the original publication and authors. The full terms of this license may be seen at: http://creativecommons.org/licences/by/4.0/legalcode

Vol. 9, No. 6, 2019, Pg. 613 - 623

Full Terms \& Conditions of access and use can be found at http://hrmars.com/index.php/pages/detail/publication-ethics 


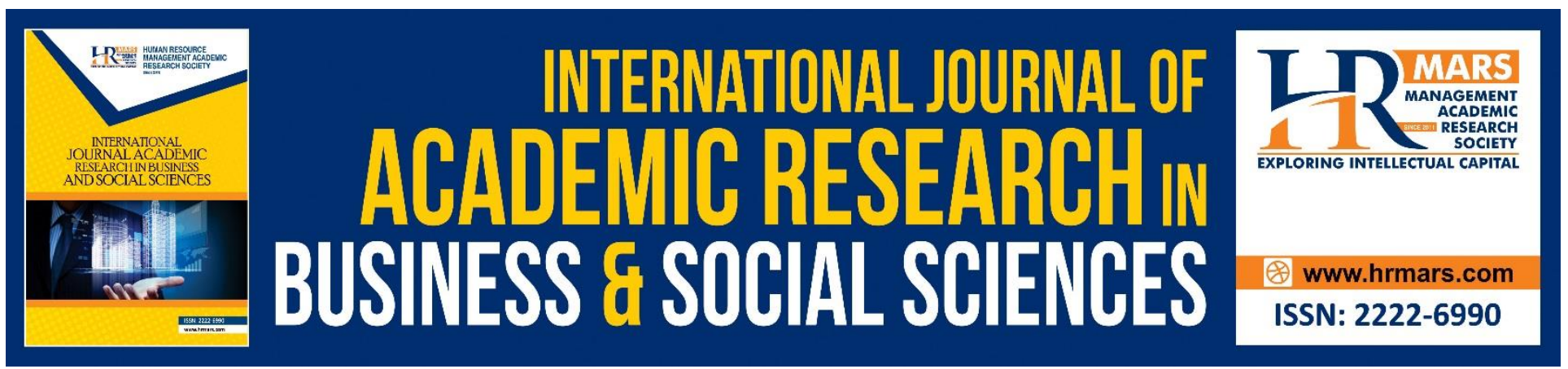

\title{
Assessing The Relationship between Sponsor Image Formation towards Building Positive Sponsor's Image
}

\author{
Wan Soraya Wan Abdul Ghani, Nurakmal Ramli, Muhammad \\ Wafaruddin Saipul Bakhry, Nur Farhana Mohd Sah, Tengku Elena \\ Tengku Mahamad
}

Faculty of Business and Management, Universiti Teknologi MARA Selangor, Malaysia

\begin{abstract}
The reciprocity practice between sponsored body engagements and image improvements represent the most important objectives for the company. Sponsorship openings is vital in developing the positive image strategies. The objective of this study is to analyze the growing importance regarding the influential relationship between sponsor image formations toward sponsor's image. It is pertinent to improve the utilization of to what extent the brand sponsorship affects the image of sponsoring bodies. This study will be conducted using empirical data to examine the relationship by adopting the criterion of sponsor image formation to result the improvisation of sponsor's image. Three distinct forms were taken based on proposition by Grohs \& Reisinger (2014) of proposed relationship between event image, event sponsor-fit and event commercialization to sponsor's image. This paper concludes with some reasons for the findings, implications for the choice and design of sponsorships, and further areas for research.
\end{abstract}

Keywords: Event Image, Event Sponsor-Fit, Event Commercialization, Sponsor's Image

\section{Introduction}

The notion of brand image is fundamental in understanding the relationship of sponsor image formation towards the positive image of sponsors. Participants' identification with the brand should logically increase the transfer of positive associations regardless of the different theoretical foundations of image transfer (Grohs \& Reisinger, 2014). Therefore, event organizer needs to grasp the importance and implication of the event as according to its goal to eventually benefit the sponsor (Getz, 2005). Sponsor's image is a role of the image with sponsored activity and the fit between the event and the sponsor (Grohs, Vsetecka, \& Wagner, 2004). Gradually, sponsorship permits the focused-on activities and serves to better position the brand and its image (Derbaix \& Lardinoit, 2001). The benefits gained from the sponsorship has become an important policy for the business 
INTERNATIONAL JOURNAL OF ACADEMIC RESEARCH IN BUSINESS AND SOCIAL SCIENCES Vol. 9, No. 6, June, 2019, E-ISSN: 2222-6990 @ 2019 HRMARS

user concept (Brown, Pope, \& Voges, 2003). While firms go into sponsorship courses of action with several of goals, two of the most critical were to increase brand awareness and to set up, reinforce or changing the brand image (Meenaghan, 2001). Past research stated that the growth of brand awareness and strengthen the image of sponsor's brand are the indicators that motivates sponsorship (Zarantonello \& Schmitt, 2015).

However, message delivery can rather be difficult as image projection of the sponsors might differ with attendees' acceptance (Cornwell, Humphreys, Maguire, Weeks \& Tellegen, 2006). Nevertheless, favourable brand image can be obtained with proven objectives that associates with consumers' need (Pitts \& Slattery, 2004). In addition, perspective of the brand can be associated with the image of the event, thus reflected by the occasion's connections held in consumers' memory (Keller, 1993). Therefore, image of the sponsors depends upon elements that related to the consumers (Piva, Cerutti, Prats \& Raj, 2017). Hence, it explains the impact of event image, eventsupport fit, event commercialization and on sponsor's image (Grohs \& Reisinger, 2014). It is important that potential sponsors organize their sponsorship to be an act of goodwill rather than an act of selfpromotion (Bruhn \& Holzer, 2015). The study will extract the practicality of brand sponsorship towards sponsor's image formation process. The research will focus on music festival event held in Malaysia. The researchers believe that the study contributes to a deeper understanding of the mechanism underlying and will eventually benefits sponsoring companies in term of the findings that lead to suggestions on conceptualization of elements that improve the projected image effectively.

Numerous studies have found that the image of the event can be transferred to the sponsor's brand (Dardis, 2009). The research clarified event's image is based on three variables: type of event, characteristics and individual factors (Brown, Pope, \& Voges, 2003). The aim is creation of event value that linked with emotions and attitude towards the sponsors (Gwinner \& Eaton, 2013). The brand sponsorship and event image are framed similarly through the general population's recollections. This exchanges to the support by a connection of the event to the brand in a sponsorship setting (Gwinner \& Eaton, 2013). It is important to distinguish that the goal of the sponsors is to target their transfer values (Chien, Cornwell \& Stokes, 2005). However, not all components been tested in all event genre or occasion therefore, diverse types of event genre may have resulted different acceptance by the consumers. The mind of consumers may have divided into functional and abstract functions. In addition, characteristic of the sponsor's product or service will establish the association between positive image transferred to the sponsoring brand at the event (Biscaia, Correia, Rosado, Ross \& Maroco, 2013).

Sponsor-fit can be perceived from the likeness of images, personalities and associations mutuality in general sense (Becker-Olsen, 2003). The sponsor fit is an important factor in determining how market respond to the sponsoring company (Biscaia et al., 2013). Besides, fit can regulate the volume of thought that consumers give to the relationship between sponsor and the event (BeckerOlsen \& Simmons, 2002) therefore able to influence consumers' attitudes and beliefs. Sponsoring brand fit may influence the image transfer. The researcher echoed from the past research that the sponsor fit has been displayed as a mediator (Dardis, 2009). Additionally, sponsor-fit depends on consumer perceptions through functional (sponsor's product used at the event) and image dimensions traits related with the event overlay with traits related with the sponsor (Gwinner \& 
Eaton, 2013). Sponsor that has been perceived positively by the consumers will received positive sentiment towards the image of the sponsor (Harvey, 2001).

Over the years, past researchers found that image transfer from sponsoring brand has been heightened when respondents professed either a functional (brand is used in the event) or image based (abstract perceptions) similarity that indirectly associate between the event and brand (Gwinner \& Eaton, 2013). However, concerning the sponsorship setting, past research indicated identifiable evidence in comprehension of the sponsor fit and resulted positive view towards the sponsors and consumers (Gwinner \& Eaton, 2013). According to the product match-up hypothesis from advertising research, positive relation achieved between perceived event- sponsor fit and perceived sponsor image (Meenaghan, 2001). However, there is an argument of sources involved and perceived match with perceptions in a portfolio context remain unexamined although the literature advances dimensions used to assess sponsor-property fit (McDonald, 1991).

Commercialization of event referring to the event been inked with commercial activities initiated for the sponsors that relate with event conceptualization (Lee \& Cho, 2008). Boosterism arose the unique proposition of event whereby it is used to 'boost' the attendees of the event (Pike, 2014). It has eventually emerged as a key feature that help differentiate the event from their competitor. Thus, strategic patterning been developing to achieve multiple outcome over event strategies (Ziakas \& Boukas, 2014). Past research stated that attitudes toward event commercialization reflect consumer reactions to these activities (Lee $\&$ Cho 2008). However, there were growing concerns with event losing the personality by over commercialized the content to ensure the development of outstanding events (Bruhn \& Holzer, 2015). The statement arises as by doing over-marketed towards achieving event fulfilment may have the negative effects to the stakeholders. Therefore, it will lead to the development of negative attributions of sponsorships (Dean, 2002). Consequently, participant and stakeholder create negative attributions of sponsorships as it has been overshadowed by the commercialization (Dean, 2002). Regardless, commercialization requires investment abiding authenticity of the event itself (Matheson, Rimmer \& Tinsley, 2014) as there are good arguments for not exploiting the aim of the event by over-commercializing it (Brida, Disegna \& Scuderi, 2014).

Sponsorship is the investment that has been made by the company to gain projected image with certain target participants (Biscaia et al., 2013). The likelihood of corporate, or association, picture has been considered from various displaying view. This is due to the image that has been the most important communication objectives that link with sponsorship goals (Fullerton, 2007). The sponsor's image interrelated with the valuation by the consumers' and research shows that highly attached participants will develop positive image throughout the sponsor and will mention good things about the sponsor (Tsiotsou \& Alexandris, 2009). Moreover, image as what was portrayed as the aggregate of feelings, perspectives, and impressions that consumers holds for an association with the sponsor (Barich \& Kotler, 1991). Besides, the term image transfer 'characterizes the exchange of these relationship to the brand or organization to sponsor (Gwinner \& Eaton, 2013). The argument is to stimulate feelings and demeanours toward the support, connecting it to the values of the event. Sponsor's image takes place if the image has positively affected the favourable image of sponsor. 
INTERNATIONAL JOURNAL OF ACADEMIC RESEARCH IN BUSINESS AND SOCIAL SCIENCES

Vol. 9, No. 6, June, 2019, E-ISSN: 2222-6990 @ 2019 HRMARS

\section{Conceptual Framework}

The proposition investigated in this paper is the insight of the framework of the research by sponsor image formation as outlined below:

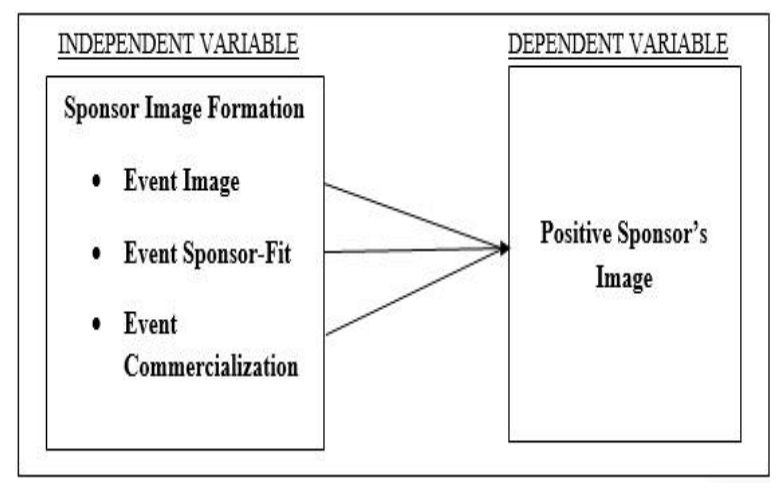

Figure 1: The Conceptual Framework in the relationship of Brand Sponsorship (Event Image, Event Sponsor-Fit and Event Commercialization) towards positive on sponsor's image (Grohs \& Reisinger, 2014).

\section{Hyphothesis}

$\mathrm{H} 1$ There is a significant relationship between sponsor image formation towards positive sponsor's image

$\mathrm{H} 1 \mathrm{a}$ There is a significant relationship between event image towards positive sponsor's image $\mathrm{H} 1 \mathrm{~b}$ There is a significant relationship between event sponsor-fit towards positive sponsor's image $\mathrm{H} 1 \mathrm{c}$ There is a significant relationship between event commercialization towards positive sponsor's image

\section{Methodology}

The paper primarily used correlation study to facilitate the decision to test variables that been used as predicament for the criterion. Descriptive analysis also been used to analyze the given data. A selfadministered survey was conducted with 120 sets of questionnaires were distributed to the respondents at the music festival. The highlights of the event are the concert. A total set of 120 questionnaires were distributed using convenience sampling to the attendees.

The response rate for this study was $100 \%$ and thus, total questionnaires analyzed were $100 \%$ $(n=120)$ from the sample size. SPSS software version 23 was used to analyze the data. The questionnaire items were adapted from Grohs \& Reisinger (2014) that measures sponsor image formation with three dimensions in it. Satisfaction was measured by 5- item scale which was adapted (Rosenbaum \& Wong, 2010). All items for event performance and attendees' satisfaction were assessed with 5-point Likert scale ranging from "strongly disagree (1) to "strongly agree (5). Descriptive analysis, reliability analysis and correlation analysis were conducted to analyse the data. Reliability analysis was performed to measure the consistency of the item by using Cronbach's Alpha. 
INTERNATIONAL JOURNAL OF ACADEMIC RESEARCH IN BUSINESS AND SOCIAL SCIENCES Vol. 9, No. 6, June, 2019, E-ISSN: 2222-6990 @ 2019 HRMARS

Results

Profile of Respondents ( $n=120)$

Table 1: Profile of respondents

\begin{tabular}{|c|c|c|c|}
\hline Items & & Frequency & Percentage \\
\hline \multirow{2}{*}{ Gender } & Male & 85 & 70.8 \\
\hline & Female & 35 & 29.2 \\
\hline \multirow{3}{*}{ Age } & $\begin{array}{l}19 \text { years } \\
\text { and } \\
\text { below }\end{array}$ & 20 & 16.7 \\
\hline & $\begin{array}{l}20-29 \\
\text { years } \\
\text { old }\end{array}$ & 84 & 70 \\
\hline & $\begin{array}{l}30-39 \\
\text { years } \\
\text { old }\end{array}$ & 16 & 13.3 \\
\hline \multirow{4}{*}{$\begin{array}{l}\text { Education } \\
\text { Level }\end{array}$} & Diploma & 41 & 34.2 \\
\hline & $\begin{array}{l}\text { Bachelor } \\
\text { Degree }\end{array}$ & 55 & 45.8 \\
\hline & Master & 5 & 4.2 \\
\hline & Others & 19 & 15.8 \\
\hline \multirow{3}{*}{$\begin{array}{l}\text { Frequency } \\
\text { attend } \\
\text { music } \\
\text { festival }\end{array}$} & $1-3$ & 10 & 8.3 \\
\hline & $\begin{array}{l}4-6 \\
7-9\end{array}$ & $\begin{array}{l}35 \\
44\end{array}$ & $\begin{array}{l}29.2 \\
36.7\end{array}$ \\
\hline & $\begin{array}{l}\text { More } \\
\text { than } 9\end{array}$ & 31 & 25.8 \\
\hline $\begin{array}{l}\text { Familiar } \\
\text { with the } \\
\text { sponsor's } \\
\text { brand }\end{array}$ & $\begin{array}{l}\text { Yes } \\
\text { No }\end{array}$ & $\begin{array}{l}118 \\
2\end{array}$ & $\begin{array}{l}98.3 \\
1.7\end{array}$ \\
\hline
\end{tabular}


As shown in Table 1, out of the 120 of respondents, male represented $70.8 \%$ of the attendees and female 29.2\%. Most of the respondents aged between $20-29$ years old with 84 (70\%) of respondents and only 16 (13.3\%) respondents aged 30-39 years old and above. With regards to education level, 55 (45.8\%) have Bachelor Degree and 5 (4.2\%) with Master. The data reveals that 44 (36.7\%) respondents with frequency of 7-9 times attend music festival followed with 35 (29.2\%) 4-6 frequency, 31 (25.8\%) more than 9 frequency and a smaller part of respondents $10(8.3 \%)$ attend music festival with 1-3 frequency. It indicates that 118 (98.3\%) respondents familiar the sponsor's brand that sponsored the event and a few number of respondents 2 (1.7\%) did not know and not familiar with the brand.

Table 2: Result of Reliability Analysis ( $n=120)$

\begin{tabular}{|l|l|l|l|}
\hline Variables & $\begin{array}{l}\text { Cronbach's } \\
\boldsymbol{\alpha}\end{array}$ & $\begin{array}{l}\text { Number } \\
\text { Item } \\
(\mathrm{n}=6)\end{array}$ & $\begin{array}{l}\text { Degree of } \\
\text { Reliability }\end{array}$ \\
\hline Event Image & .662 & 6 & Moderate \\
\hline Event sponsor-fit & .674 & 6 & Moderate \\
\hline $\begin{array}{l}\text { Event } \\
\text { Commercialization }\end{array}$ & .739 & 6 & Good \\
\hline Sponsor's image & .608 & 6 & Moderate \\
\hline
\end{tabular}

Table 2 indicates the result of reliability analysis Reliability can be referred as the degree of scale that generates reliable result if repetitive measurement made. It was performed to make sure the reliable measurement from time to time by using this tool. A Cronbach's Alpha is a reliability coefficient that indicated how well the items in a set are positive correlate to one another. From the result shown above, it can be concluded that the reliability of the items is moderate for the event image, event sponsor-fit, and sponsor's image while event commercialization is good reliability and all acceptable to be used as survey questions to respondents.

Table 3: Mean and Standard Deviation

\begin{tabular}{|l|l|l|l|}
\hline & $\mathrm{N}$ & Mean & SD \\
\hline Event Image & 120 & 3.10 & .543 \\
\hline Event sponsor-fit & $\mathbf{1 2 0}$ & $\mathbf{3 . 2 8}$ & $\mathbf{. 5 1 9}$ \\
\hline $\begin{array}{l}\text { Event } \\
\text { Commercialization }\end{array}$ & 120 & 2.95 & .590 \\
\hline
\end{tabular}

Table 3 shows the finding of mean and standard deviation for independent variable. Comparing the mean among the items, the highest mean is sponsor-fit with 3.28 which means it is the most dominant factor towards sponsor's image. The second highest mean is 3.10, event image. Meanwhile, the lowest mean is 2.95 , event commercialization. 
Table 4: Correlation analysis

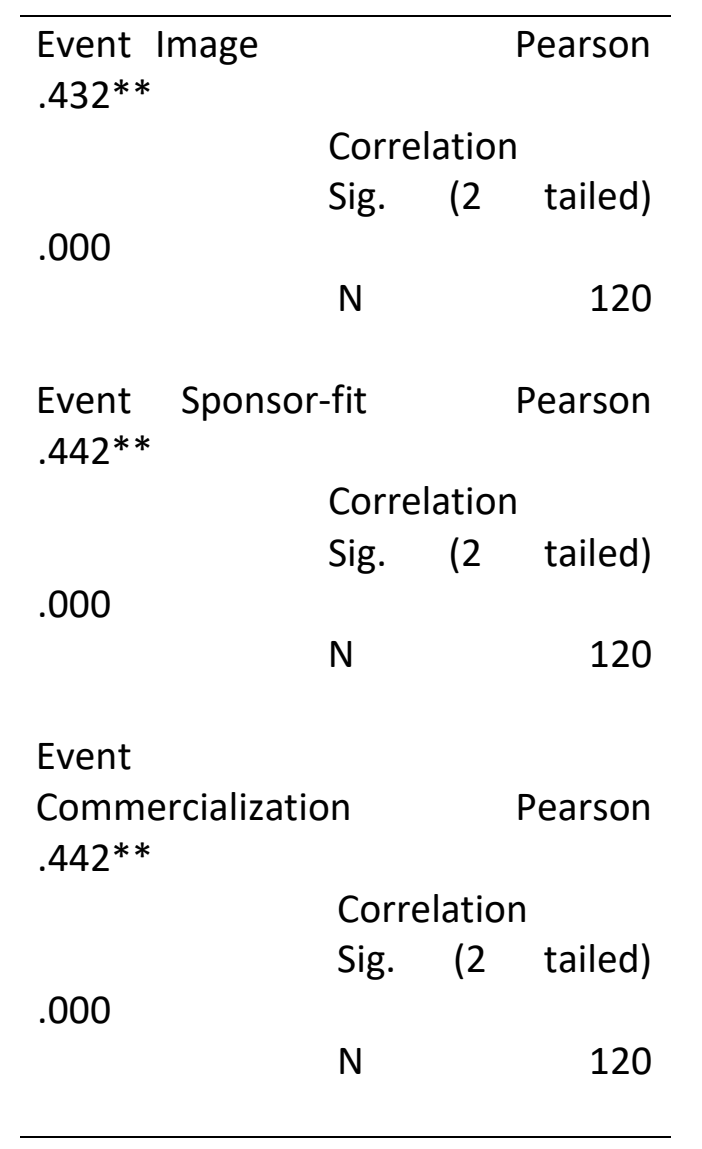

Correlation analysis was performed to examine the relationship between sponsor image formation formation to result the improvisation of sponsor's image. The Pearson Correlation was performed to assess the association between the three distinct forms and sponsor's image. Result shows that there is a significant relationship between the finding of the relationship between event image and sponsor's image $(r=0.432, p=0.000)$. Next, event sponsor-fit indicates $(r=0.442, p=0.000)$ and event commercialization $(r=0.442, p=0.000)$.

Table 5: Summary of hypothesis testing

\begin{tabular}{ll}
\hline Hypothesis & Result \\
\hline H1a: Event Image - Positive Sponsor's & Supported \\
Image & \\
H1b: Event Sponsor-fit - Positive & Supported \\
Sponsor's Image & \\
H1c: Event Commercialization & Supported
\end{tabular}


INTERNATIONAL JOURNAL OF ACADEMIC RESEARCH IN BUSINESS AND SOCIAL SCIENCES

Vol. 9, No. 6, June, 2019, E-ISSN: 2222-6990 @ 2019 HRMARS

Therefore, it can be concluded that $\mathrm{H} 1 \mathrm{a}, \mathrm{H} 1 \mathrm{~b}$ and $\mathrm{H} 1 \mathrm{c}$ are all accepted.

\section{Discussion}

The main objective of this study is to assess the relationship between the criterion of sponsor image formation that based from proposition by Grohs \& Reisinger (2014) and does it reflect to the improvisation of sponsor's image. Descriptively, majority of the respondents agreed with event image as the most dominant component. The target audience need to be identified to sync the image that the sponsors try to represent. Based on correlation analysis, the positive relationship between the sponsor image formation is consistent with the findings conducted together with other research (Grohs \& Reisinger, 2014). The summary of hypothesis testing between event image, event sponsorfit and event commercialization as part of sponsor image formation shown in Table 5. Nevertheless, all three variables get moderate relationship. Music festival tended to get the share of sponsorship investment, in part because of the widespread media coverage that they get (Guedon \& Kristensen, 2014). However, it is vital to focus on advantageous with bigger scope event that could relate the target audience with the promoted brand to give maximum benefit to the sponsors.

\section{Conclusion}

Future recommendations should be taken into consideration for further. Research which related to sponsor image formation should be conducted occasionally in different music festival. This is to ensure the data and trends of the respondents in the event can be made into comparison. Thus, add the value of the academic study to the industrial practices in order to confirm these results and explain in more depth the factors which determine the positive sponsor's image can be achieved. The indication of methods or techniques can be varied such as interview session or observation for detailed explanation and feedback rather than solely rely on questionnaires method. Furthermore, the respondents can be expanded for the realiablity purposes as the research sample of the study is limited to the attendees at the festival event. Larger sample size and different location may give different result. Moreover, future studies may consider replicating the study at different setting with different types of events such as sports, cultural events and festivals.

The findings provide beneficial insights towards sponsor's image. Accordingly, it will lead to a point for the sponsors. For instance, musical instruments company has bigger chance to fit with music festival genre. The findings can be applied by event organizer to improve the quality of event performance thus lead to the success of an event. Event organizers need to explore the uniqueness and provide special features for the overall event. To attract attendees to the event, few factors are in need for consideration to differentiate from other similar genre of event.

\section{Acknowledgement}

We would like to show our gratitude to Universiti Teknologi MARA (UiTM) and Faculty Business and Management for the support. 
INTERNATIONAL JOURNAL OF ACADEMIC RESEARCH IN BUSINESS AND SOCIAL SCIENCES

Vol. 9, No. 6, June, 2019, E-ISSN: 2222-6990 @ 2019 HRMARS

\section{Corresponding Author}

Wan Soraya bt Wan Abdul Ghani, Department of International Business and Management Studies, Faculty of Business and Management, Universiti Teknologi MARA Selangor, Malaysia.

Email: wansor2956@puncakalam.uitm.edu.my

\section{References}

Barich, H. \& Kotler, P. (1991). A framework for marketing image management, Sloan Management Review, 32(2), 94-104.

Becker-Olsen, K. L. (2003). And now, a word from our sponsor. Journal of Advertising, 32(2), 17-32.

Becker-Olsen, K. L, \& Simmons, C. J. (2002). When do social sponsorships enhance or dilute equity? fit, message source and the persistence of effects. Advances in Consumer Research, 29, 287289.

Biscaia, R., Correia, A., Rosado, A. F., Ross, S. D., and Maroco, J. (2013). "Sport Sponsorship: The Relationship Between Team Loyalty, Sponsorship Awareness, Attitude Toward the Sponsor, and Purchase Intentions", Journal of Sport Management, 27(4).

Brida, J. G., Disegna, M., \& Scuderi, R. (2014). Segmenting visitors of cultural events: The Case of Christmas Market Expert Systems with Applications, 41(10) , 4542-4553.

Brown, M. R., Pope, N. K. L., \& Voges, K. E. (2003). An examination of the effect of sponsorship stimuli on consumer perceptions of concrete and abstract brand attributes. ANZMAC Conference Proceedings Adelaide.

Bruhn, M., \& Holzer, M. (2015). The role of the fit construct and sponsorship portfolio size for event sponsorship success: A field study, European Journal of Marketing, 49(5/6), 874-893. https://doi.org/10.1108/EJM-10-2013-0594.

Chien, P. H. M., Cornwell, T. B., \& Pappu, R. (2011). Sponsorship portfolio as a brand-image creation strategy. Journal of Business Research, 64, 142-149.

Chien, P. H. M., Cornwell, T. B., \& Stokes, R. (2005). A Theoretical Framework for Analysis of Image Transfer in Multiple sponsorships. ANZMAC Conference Fullerton, Sam (2007). Sports Marketing. New York: McGraw-Hill.

Cornwell, T. B., Humphreys, M. S., Maguire, A. M., Weeks, C. S., \& Tellegen, C. L. (2006). SponsorshipLinked Marketing: The Role of Articulation in Memory. Journal of Consumer Research, 33(3), 312-321.

Dardis, F. E. (2009). Attenuating the negative effect on perceived incongruence in sponsorship: How message repetition can enhance evaluations of an "incongruent" sponsor", Journal of Promotion Management, 15(1-2), 36-56.

Dean, D. H. (2002). "Associating the corporation with a charitable event through sponsorship: Measuring the effects on corporate community relations", Journal of Advertising, 31, (4.)

Derbaix, C., \& Lardinoit, T. (2001). Sponsorship and Recall of Sponsors. Psychology and Marketing, $18(2), 167-190$.

Fullerton, S. (2007). Sports Marketing. New York: McGraw-Hill.

Getz, D. (2005). Event Management and Event Tourism, 2nd Ed, Cognizant Communication Corporation, New York, NY. 
INTERNATIONAL JOURNAL OF ACADEMIC RESEARCH IN BUSINESS AND SOCIAL SCIENCES

Vol. 9, No. 6, June, 2019, E-ISSN: 2222-6990 @ 2019 HRMARS

Grohs, R., \& Reisinger, H. (2014). "Sponsorship effect on brand image: The role of the exposure and activity involvement", Journal of Business Research, 67(5), 1018-1025.

Grohs, R., Vsetecka, S., \& Wagner, U. (2004). Assessing the Effectiveness of Sport Sponsorships: An Empirical Examination. Schmalenbach Business Review, 56, 119-138.

Gwinner K., P. \& Eaton, J. (2013). Building Brand Image Through Event Sponsorship: The Role of Image Transfer, Journal of Advertising, 28:4, 47-57.

Guedon, V., \& Kristensen, D. G., (2014). Sponsorship Effects on Music Festival Participants. Copenhagen Business School, Service Management.

Harvey, B. (2001). Measuring the effects of sponsorships. Journal of Advertising Research, 41, 59-65.

Keller, K. L. (1993). "Conceptualizing, measuring, and managing customer-based brand equity", Journal of Marketing, 57, 1.

Lee, H. S., \& Cho, C. H. (2008). The matching effect of brand and sporting event personality: sponsorship implications. Journal of Sport Management, 23 (1), pp. 41-64.

Matheson, C., Rimmer, R., \& Tinsley, R. (2014). Spiritual attitudes and visitor motivations at the Beltane Fire Festival, Edinburgh. Tourism Management, 44, 16-33.

McDonald, C. (1991). Sponsorship and the image of the sponsor. European Journal of Marketing, 25(11), 31-38.

Meenaghan, T. (2001). "Understanding sponsorship effects”, Journal of Psychology and Marketing, 18(2), pp.95-122.

Pike, S. (2014). Destination marketing organizations and destination marketing: A Narrative Analysis of The Literature Tourism Management, 41, 202-227.

Pitts, B., \& Slattery, J. (2004). An Examination of the Effects of Time on Sponsorship Awareness Levels. Sport Marketing Quarterly, 13, 43-54.

Piva, E., Cerutti, S., Prats, L., \& Raj, R. (2017). Enhancing Brand Image through Events and Cultural Festivals: the Perspective of the Stresa Festival's Visitors. Almatourism - Journal of Tourism, Culture and Territorial Development, 8(15), 99-116. doi:https://doi.org/10.6092/issn.2036$5195 / 6888$

Tsiotsou, R., \& Alexandris, R. (2009). Delineating the outcomes of sponsorship: sponsor image, word of mouth and purchase intentions. International Journal of Retail and Distribution Management, 37(4), 358-369. https://doi.org/10.1108/09590550910948583

Rosenbaum, M. S. \& Wong, I. N. (2010). Value equity in event planning: A Case Study of Macau. Marketing Intelligence \& Planning, 28(4), 403-417.

Wakefield, K. L. \& Bennett, G. (2010). "Affective intensity and sponsor identification", Journal of Advertising, vol.39, Issue 3, 99-111.

Zarantonello, L., \& Schmitt, B. H. (2015). The impact of Event Marketing on Brand Equity, International Journal of Advertising, 32:2, 255-280.

Ziakas, V., \& Boukas, N. (2014). Contextualizing phenomenology in event management research: Deciphering the meaning of event experiences. International Journal of Event and Festival Management, 5(1), 56-73. 